\title{
Management of the Perineum in Normal Physiologic Birth: A Joint Collaboration of Women and Midwives
}

\author{
Somayeh Makvandi ${ }^{1}$ and Khadigeh Mirzaiinajmabadi ${ }^{2 *}$ \\ ${ }^{1}$ PhD candidate on reproductive health, School of Nursing and Midwifery, Mashhad University of Medical Sciences, Mashhad, Iran \\ ${ }^{2}$ Department of Midwifery, School of Nursing and Midwifery, Mashhad University of Medical Sciences, Mashhad, Iran
}

*Corresponding author: Khadigeh Mirzaiinajmabadi, PhD, Associate Professor, Department of Midwifery, School of Nursing and Midwifery, Mashhad University of Medical Sciences, Mashhad, Iran, Tel: 0098-9123740580; Fax: 009851 38597313; Email: MirzaiiKH@mums.ac.ir

Submission: 眥 February 21, 2018; Published: 眥 February 27, 2018

\section{Opinion}

Perineal trauma during childbirth is mainly connected with pain and complications. Episiotomy is a surgical incision of the perineum and the posterior vaginal wall. Before setting up motherfriendly care in Iran, mediolateral episiotomy was a traditional and routine component of vaginal childbirth. The aim was to keep away from damage to the anal sphincter and to limit the risk of traumatic birth for the fetus. In Iran, mother-friendly hospitals started their activity in 2008. A mother-friendly hospital must to promote and support normal physiologic birth that is the vaginal delivery with minimal interventions including routine episiotomies [1]. Evidences comparing routine and restrictive use of episiotomy during spontaneous vaginal birth propose that there are significant advantages in adopting a restrictive approach, particularly a reduction in posterior perineal lacerations [2-4].

According to Iran's Health Ministry's policies, the overall ideal episiotomy rate should be less than $30 \%$ and each motherfriendly hospital is required to reduce the episiotomy rate by $10 \%$. Maintaining women's perineal integrity is a highly respected point in physiologic childbirth techniques. In the physiologic birth program, expectant women are advised to perform a perineal massage six to eight weeks prior to birth. Antenatal perineal massage increases both the overall health and elasticity of the perineum. Also, pregnant women who perform Kegel or pelvic floor exercises often find they have more intact perineum during delivery. A full Kegel involves pulling up and then pulling in or engaging the inner muscles and then the surface muscles of the pelvic floor.
In the second stage of labor, a slow and controlled birth of the baby is believed to be of significance to prevent perineal injury. The women should let their bodies tell them when to push. The whole reason the pushing stage is a slow process is to permit their tissues time to stretch. Application of the "Hands-off" approach for delivery of fetal head and support the birth of the shoulders by mid wives has a positive effect on protecting the integrity of perineum and reducing the number and severity of perineal lacerations. As mentioned above, in the physiologic birth program maintaining an intact perineum is a joint collaboration between women and midwives.

\section{References}

1. Anational guide for normal delivery and the provision of pharmacological and non-pharmaceutical methods for reducing labor pain. Iran's Ministry of Health and Medical Education. Maternity Health Office, Family and Population Health Office.

2. Yamasato K, Kimata C, Huegel B, Durbin M, Ashton M, et al. (2016) Restricted episiotomy use and maternal and neonatal injuries: a retrospective cohort study. Arch Gynecol Obstet 294(6): 1189-1194.

3. Venus D, Rao PS, Prajwal S (2017) Comparison of use of restrictive episiotomy versus routine episiotomy in primigravidae undergoing vaginal birth at a tertiary care hospital. International Journal of Reproduction, Contraception, Obstetrics and Gynecology 6(5): 17701776.

4. Asokan KM, Santhosh S (2016) Routine episiotomy causes more morbidity in parous women, a case controlled study conducted in Kannur Medical College. Age 23: 2-6. 
cc) (P) Creative Commons Attribution 4.0

International License

For possible submissions Click Here

Submit Article
Your subsequent submission with Crimson Publishers will attain the below benefits

- High-level peer review and editorial services

- Freely accessible online immediately upon publication

- Authors retain the copyright to their work

- Licensing it under a Creative Commons license

- Visibility through different online platforms

- Global attainment for your research

- Article availability in different formats (Pdf, E-pub, Full Text)

- Endless customer service

- Reasonable Membership services

- Reprints availability upon request

- One step article tracking system 